\title{
Correction to: Salinomycin effectively eliminates cancer stem-like cells and obviates hepatic metastasis in uveal melanoma
}

\author{
Jingfeng Zhoư ${ }^{\dagger}$ Shenglan Liư ${ }^{\dagger}$ Yun Wang, Wei Dai, Hailin Zou, Shubo Wang, Jing Zhang and Jingxuan Pan*
}

\author{
Correction to: Mol Cancer 18, 159 (2019). \\ https://doi.org/10.1186/s12943-019-1068-1
}

After publication of the article [1], the authors realized one misplaced image in Fig. 2a and Fig. 2d, respectively, which prompted us to request correction. These errors inadvertently happened during the stage of our figure assembly with photoshop microsoftware. The corrected version of Fig. 2a and Fig. 2d is provided. The correction does not affect the conclusion or discussion of this article. The authors deeply apologize to readers the inconvenience caused by the unconscious mistakes and appreciate the correction opportunity.
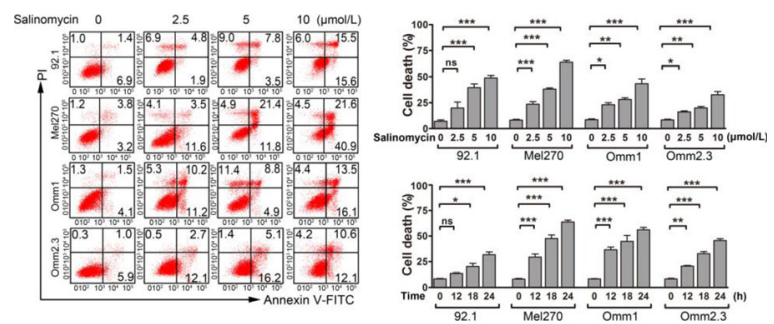

Fig. 2 a. Annexin V/PI apoptotic assay was performed in the UM cells treated with escalating concentrations of salinomycin for $24 \mathrm{~h}$ or at $10 \mu \mathrm{mol} / \mathrm{L}$ for various exposure

The original article can be found online at https://doi.org/10.1186/s12943019-1068-1.

* Correspondence: panjx2@mail.sysu.edu.cn

†Jingfeng Zhou and Shenglan Liu contributed equally to this work.

State Key Laboratory of Ophthalmology, Zhongshan Ophthalmic Center, Sun Yat-sen University, 54 South Xianlie Road, Guangzhou 510060, People's

Republic of China

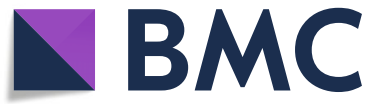

() The Author(s). 2021 Open Access This article is licensed under a Creative Commons Attribution 4.0 International License, which permits use, sharing, adaptation, distribution and reproduction in any medium or format, as long as you give appropriate credit to the original author(s) and the source, provide a link to the Creative Commons licence, and indicate if changes were made. The images or other third party material in this article are included in the article's Creative Commons licence, unless indicated otherwise in a credit line to the material. If material is not included in the article's Creative Commons licence and your intended use is not permitted by statutory regulation or exceeds the permitted use, you will need to obtain permission directly from the copyright holder. To view a copy of this licence, visit http://creativecommons.org/licenses/by/4.0/ The Creative Commons Public Domain Dedication waiver (http://creativecommons.org/publicdomain/zero/1.0/) applies to the data made available in this article, unless otherwise stated in a credit line to the data. 